\title{
Variability of morphological, physical and chemical properties of soils derived from carbonate-rich parent material in the Pieniny Mountains (south Poland)
}

\begin{abstract}
Carbonate-rich soils are characterized by great diversity in content of carbonate and non-carbonate mineral substances in soil substrate which largely influences soil properties. The study presents the analysis results of four soil profiles located at the area of Pieniny National Park. The aim of this study was to characterize and classify the soils developed from the mixture of carbonate and carbonate-rich rock material, formerly classified as pararendzinas. It was achieved by determination of morphological, physical, and chemical properties, as well as mineralogical composition of selected carbonate-rich soils occurring in the Polish part of the Pieniny Mts. Soils were classified as typical chernozemic rendzina (P1), typical eutrophic brown soils (P2, P4), as well as typical pararendzina (P3) according to Polish Soil Classification (2011).

The parent material of studied soils P1, P2 and P4 were slope covers, with a dominant share of sandstone and minor share of limestone, whereas soil P3 was formed from variegated shale cut with multiple calcite veins. Soils were characterized by stable aggregate structure: crumby, angular blocky and subangular blocky. They were medium or strong skeletal, mostly with loam texture with great share of silt fraction. $\mathrm{CaCO}_{3}$ content in genetic horizons ranged from 0.0 to $703.0 \mathrm{~g} \cdot \mathrm{kg}^{-1}$. The reaction of studied soils was from weakly acidic to alkaline. Analysed soils were characterized by very high base saturation. Among determined exchangeable cations, $\mathrm{Ca}^{2+}$ ions had the biggest share in all analysed profile. High base saturation, as well as high content of calcium carbonate was accompanied by content of organic matter and percentage content of clay fraction. Taking into consideration determined chemical and physical properties, it can be found that investigated soils were influenced by not only the in-situ weathering material but also by rock material which have been transported and deposited as a result of slope processes. Furthermore, the lack or lower content of $\mathrm{CaCO}_{3}$ in surface and middle part of analysed soil profiles was most likely a result of the impoverishment of rock material during the transport on the slope.
\end{abstract}

Keywords: carbonate-rich soils, Carpathian's soils, Phaeozems, Cambisols, Regosols

\section{INTRODUCTION}

Diversification of soil cover at the area of the Pieniny Mts. is conditioned by variability of geological substrate and morphology of the terrain (NiemyskaŁukaszuk et al. 2002, Skiba et al. 2002, Zaleski et al. 2006). The most frequently occurring carbonate rocks in the area of Pieniny National Park (PNP) include (1) limestone and marl, which are parent rock of rendzinas, (2) clastic rocks with a high carbonate content mixed with fragments of limestone, from which pararendzinas are form, as well as (3) sandstone and shale that has an insignificant admixture of carbonate cement, from which soils with cambic horizons are formed (Niemyska-Łukaszuk et al. 2002, 2004). Carbonate-rich soils are characterized by specific calcium-silicate soil substrate which largely influences soil properties (Zagórski 2001). Percentage share of the areas of individual soil taxonomic units within PNP are determined by the lithogenic relations. Carbonate-rich soils characterized by different degrees of development occupy $60 \%$ of the PNP area (Niemyska-Łukaszuk et al. 2002, 2004).

Formerly in Pieniny Mts. area, all soils developed on rocks enriched in carbonates as well as soils formed on slope covers containing mixture of weathered carbonate and non-carbonate rocks were classified as pararendzinas (Adamczyk et al. 1980). In a wider range pararendzinas were studied by Zasoński (1981, 1992, 1993, 1995a, 1995b), who described pararendzinas from area of Eastern Carpathians, Cieszyn area and Rymanów Hills (Table 1). Furthermore, Niemyska-Łukaszuk et al. $(2002,2004,2010)$ described pararendzinas at the area of Babia Góra National Park and PNP (Table 1). Pararendzinas at the area of Pieniny were described also by Kacprzak and Żyła (2006) (Table 1). Moreover, individual profiles of pararendzinas at the area of Częstochowa Upland, Masurian Lake District, Nałęczów Plateau, Góra Zborów Nature Reserve and others were described (Kobylecka 1981, Lemkowska and Sowiński 2008, Paluszek 2010, Fajer and Waga 2012) (Table 1). Large part of these soils, 
TABLE 1. Bibliography of pararendzinas' research in Poland

\begin{tabular}{|c|c|c|c|c|}
\hline Author(s) & Location & Soil type & $\begin{array}{l}\text { Translation proposed } \\
\text { by authors }\end{array}$ & Parent material \\
\hline $\begin{array}{l}\text { Zasoński and Skiba } \\
1988\end{array}$ & $\begin{array}{l}\text { Cieszyn area, } \\
\text { Western Carphatians }\end{array}$ & $\begin{array}{l}\text { pararędzina właściwa, } \\
\text { pararędzina brunatna } \\
\text { (PTG 1989) }\end{array}$ & $\begin{array}{l}\text { proper pararendzina, } \\
\text { brown pararendzina }\end{array}$ & shale, marl, sandstone \\
\hline Kobylecka 1981 & $\begin{array}{l}\text { Kraków-Częstochowa } \\
\text { Upland, S Poland }\end{array}$ & $\begin{array}{l}\text { pararędzina } \\
\text { czarnoziemna } \\
\text { (PTG 1974) }\end{array}$ & $\begin{array}{l}\text { chermozem } \\
\text { pararendzina }\end{array}$ & limestone and marl \\
\hline Zasoński 1992 & $\begin{array}{l}\text { Miejsce Piastowe } \\
\text { and Rymanów, } \\
\text { Eastern Carpathians }\end{array}$ & $\begin{array}{l}\text { pararędzina właściwa, } \\
\text { pararędzina brunatna } \\
\text { (PTG 1989) }\end{array}$ & $\begin{array}{l}\text { proper pararendzina, } \\
\text { brown pararendzina }\end{array}$ & sandstone and shale \\
\hline Zasoński 1993 & Eastern Carpathians & $\begin{array}{l}\text { pararędzina inicjalna, } \\
\text { pararędzina właściwa, } \\
\text { pararędzina brunatna } \\
\text { (PTG 1989) }\end{array}$ & $\begin{array}{l}\text { initial pararendzina, } \\
\text { proper pararendzina, } \\
\text { brown pararendzina }\end{array}$ & sandstone and shale \\
\hline Zasoński 1995a & Eastern Carpathians & $\begin{array}{l}\text { pararędzina inicjalna, } \\
\text { pararędzina właściwa } \\
\text { (PTG 1989) }\end{array}$ & $\begin{array}{l}\text { initial pararendzina, } \\
\text { proper pararendzina }\end{array}$ & sandstone, shale and limestone \\
\hline Zasoński 1995b & Eastern Carpathians & $\begin{array}{l}\text { pararędzina brunatna } \\
\text { (PTG 1989) }\end{array}$ & brown pararendzina & shale, calcite-bearing sandstone \\
\hline $\begin{array}{l}\text { Niemyska-Łukaszuk } \\
\text { et al. } 2002\end{array}$ & Pieniny National Park & $\begin{array}{l}\text { pararędzina brunatna, } \\
\text { pararędzina } \\
\text { czarnoziemna (PTG } \\
\text { 1989) }\end{array}$ & $\begin{array}{l}\text { brown pararendzina, } \\
\text { chermozem } \\
\text { pararendzina }\end{array}$ & sandstone and shale \\
\hline $\begin{array}{l}\text { Kacprzak and Żyła } \\
2006\end{array}$ & Lesser Pieniny & $\begin{array}{l}\text { pararędzina brunatna } \\
\text { (PTG 1989) }\end{array}$ & brown pararendzina & marl and limestone \\
\hline Kacprzak et al. 2006 & $\begin{array}{l}\text { Szopczański Gorge, } \\
\text { Pieniny National Park }\end{array}$ & $\begin{array}{l}\text { pararędzina brunatna } \\
\text { (PTG 1989) }\end{array}$ & brown pararendzina & limestone and sandstone \\
\hline $\begin{array}{l}\text { Lemkowska } \\
\text { and Sowiński } 2008\end{array}$ & $\begin{array}{l}\text { Masurian Lake District, } \\
\text { NE Poland }\end{array}$ & $\begin{array}{l}\text { pararędzina właściwa } \\
\text { (PTG 1989) }\end{array}$ & proper pararendzina & glacial sediments \\
\hline $\begin{array}{l}\text { Łuszczyński and } \\
\text { Łuszczyńska } 2009\end{array}$ & $\begin{array}{l}\text { Nida Basin, } \\
\text { central Poland }\end{array}$ & $\begin{array}{l}\text { pararędzina właściwa } \\
\text { (PTG 1989) }\end{array}$ & proper pararendzina & limestone, marl and loess \\
\hline Paluszek 2010 & $\begin{array}{l}\text { Nałęczów Plateau, } \\
\text { Lublin Upland, } \\
\text { SE Poland }\end{array}$ & $\begin{array}{l}\text { pararędzina inicjalna } \\
\text { (PTG 1989) }\end{array}$ & initial pararendzina & glacial sediments - till and sand \\
\hline $\begin{array}{l}\text { Sowiński and } \\
\text { Lemkowska } 2010\end{array}$ & $\begin{array}{l}\text { Olsztyn Lake District, } \\
\text { NE Poland }\end{array}$ & $\begin{array}{l}\text { pararędzina właściwa } \\
\text { (PTG 1989) }\end{array}$ & proper pararendzina & $\begin{array}{l}\text { calcareous gyttja, calcareous clay } \\
\text { gyttja }\end{array}$ \\
\hline Rybicki 2010 & $\begin{array}{l}\text { Kielce Upland, } \\
\text { central Poland }\end{array}$ & $\begin{array}{l}\text { pararędzina inicjalna } \\
\text { (PTG 1989) }\end{array}$ & initial pararendzina & siltic sediment \\
\hline Krysiak et al. 2010 & $\begin{array}{l}\text { Radomszczańskie Hills, } \\
\text { Małopolska Upland, } \\
\text { S Poland }\end{array}$ & $\begin{array}{l}\text { pararędzina brunatna } \\
\text { (PTG 1989) }\end{array}$ & brown pararendzina & $\begin{array}{l}\text { limestone, marly limestone, } \\
\text { quaternary sand, glacial till, }\end{array}$ \\
\hline $\begin{array}{l}\text { Niemyska-Łukaszuk } \\
\text { et al. } 2010\end{array}$ & $\begin{array}{l}\text { Babia Góra National } \\
\text { Park }\end{array}$ & $\begin{array}{l}\text { pararędzina właściwa } \\
\text { (PTG 1989) }\end{array}$ & proper pararendzina & shale \\
\hline Fajer and Waga 2012 & $\begin{array}{l}\text { Góra Zborów Nature } \\
\text { Reserve, } \\
\text { Kraków-Częstochowa } \\
\text { Upland, S Poland }\end{array}$ & $\begin{array}{l}\text { pararędzina z cechami } \\
\text { brunatnienia } \\
\text { (PTG 2011) }\end{array}$ & brown pararendzinas & $\begin{array}{l}\text { fine-grain sediments (sand and silt) } \\
\text { with weathering products of } \\
\text { limeston }\end{array}$ \\
\hline Lasota et al. 2014 & $\begin{array}{l}\text { Grabowiec Nature } \\
\text { Reserve, N Poland }\end{array}$ & $\begin{array}{l}\text { pararędzina właściwa } \\
\text { (PTG 1989) }\end{array}$ & proper pararendzina & sandstone and shale \\
\hline
\end{tabular}

despite the fact, that they have been earlier classified as pararendzinas, currently would not comply with all diagnostic criteria for these soils according to PSC (2011).

The subsequent editions of Polish Soil Classification (PSC) distinguishes pararendzinas as soils formed from clastic rocks that are rich in calcium carbonate (A Natural and Genetical Classification of Polish Soil 1956, Genetical Classification of Polish Soil 1959, PSC 1974, 1989, 2011). The similar soil taxonomic units occur in German soil classification (Arbeitskreis für Bodensystematik der Deutschen Bodenkundlichen 
Gesellschaft 1998), however pararendzinas are not distinguished in international classification such as Soil Taxonomy (1999) and World Reference Base for Soil Description (IUSS Working Group WRB 2015). In the current edition of PSC (2011), pararendzinas occur in the order of weakly developed soil, within which typical pararendzinas and brown pararendzinas are distinguished. According to PSC (2011), pararendzinas are soils which contain at least $15 \%$ calcium carbonate in parent material and they are characterized by neutral or alkaline reaction $(\mathrm{pH}$ ranging from 6.0 to 7.5 ).

Referring to other authors, typical pararendzinas can be classified according to IUSS Working GroupWRB (2015) as Lithic Leptosols, Calcaric-Lithic Leptosols, Haplic Regosol (Calcaric) Haplic Calcisols (Niemyska-Łukaszuk et al. 2002, 2004; PSC 2011), whereas brown pararendzinas are classified as Calcaric Cambisols, Skeletic-Calcaric Cambisols, Haplic Regosol (Calcaric), Cambic Calcisols, Calcaric Calcisols (Skiba et al. 2002, Niemyska-Łukaszuk et al. 2002, 2004, PSC 2011).

In general, carbonate-rich soils in the Carpathian Mountains occur at small areas in the complexes with Cambisols, what is the result of spatial variability of the parent rock (Zasoński 1993, 1995a, 1995b). Formation of carbonate-rich soils accompany significant predominance of lithological features over pedogenic features. Those soils are often found in locations of landslides exposures (Zasoński 1995a). Due to the high content of rock fragments, loamy texture (e.g. sandy loam, loam, silty clay loam), as well as shallow soil profile, carbonate-rich soils are not suitable for agricultural use. Furthermore, carbonaterich soils s are frequently covered by deciduous forests. Xerothermic plant communities appearing on the rocks can be also found in places where those soils occur (Zasoński 1993, Krysiak et al. 2010, Fajer and Waga 2012).

According to Zasoński (1992), pararendzinas should differ from rendzinas what is manifested by varied carbonate content in parent material and the difference in the intensity of weathering or smaller share of carbonate debris in the soil profile (Zasoński 1993, 1995b). Pararendzinas can evolve into brown earth soils (Zasoński 1992), in particular due to advanced decalcitization process of the parent material (Zasoński 1995b). Nevertheless, pararendzinas and rendzinas in the mountain areas are similar in terms of their physical properties, e.g. grain size distribution, content of rock fragments, durability of aggregates and water retention (Niemyska-Łukaszuk 2002, Zaleski et al. 2006).

Carbonate-rich soils can have well-developed humus horizon, which is characterized by crumby structure
(Zasoński 1992, Zaleski et al. 2016). Depending on the parent rock, from which carbonate-rich soils have evolved, organic matter can occur within the soil profile (Krysiak et al. 2010, Fajer and Waga 2012). The presence of organic matter within the soil profile is characteristic especially in case when varied flysch subfacies constitute parent material (Zasoński and Skiba 1988, Zasoński 1992).

The analysis of the chemical composition of carbonate-rich soils provides an information, which is helpful to soil processes interpretation (Kacprzak et al. 2006). Within the carbonate-rich soils, depending of the parent rock, the calcium carbonate content can increase with depth. In some cases, decalcification in the middle part of soil profile can occur (Zasoński and Skiba 1988, Zasoński 1992, Zasoński 1993). Moreover, the soils are characterized by high sorption capacity (Niemyska- Łukaszuk et al. 2004, Zaleski et al. 2016).

Nowadays, within the researches over carbonate-rich soils, not many of them is focusing on pararendzinas, especially with respect to difficulties connecting with their classification. Moreover, changes in the criteria for pararendzinas classification, implemented with the update of PSC (2011), were the basis for conducting the studies over that soils occuring in the Pieniny Mts. The aim of this study was to characterize and classify the soils developed from the mixture of carbonate and carbonate-rich rock material, occurring in the Polish part of the Pieniny Mts., formerly classified as pararendzinas.

\section{MATERIALS AND METHODS}

Four soil profiles from area of PNP were investigated. Profile P1 was sampled in Tylka village, profiles P2 and P4 in Sromowce Niżne village, and profile P3 in Hałuszowa village. Colluvial material containing sandstone and smaller amounts of limestone fragments were parent materials of P1, P2 and P4 soils profile. The parent material of profile $\mathrm{P} 3$ was variegated shale cut by calcite veins (Table 2).

To identify the main mineral phases, X-ray powder diffraction analysis were performed. It was accomplished on the air-dry smaller than 2,0 mm particles of soil samples using a Philips X'Pert APD diffractometer $(\mathrm{Cu}-\mathrm{K} \alpha$ radiation generated at $40 \mathrm{kV}$ and 30 $\mathrm{mA}$ by generator $\mathrm{PW} 1870$, and equipped with vertical goniometer PW 3020) at the Institute of Geological Sciences, Jagiellonian University, Kraków, Poland. Mineralogical composition was determined only in selected horizons from profile P1, P2 and P3 (Fig.).

Soil samples underwent determination of basic physical and chemical properties. Color according to 


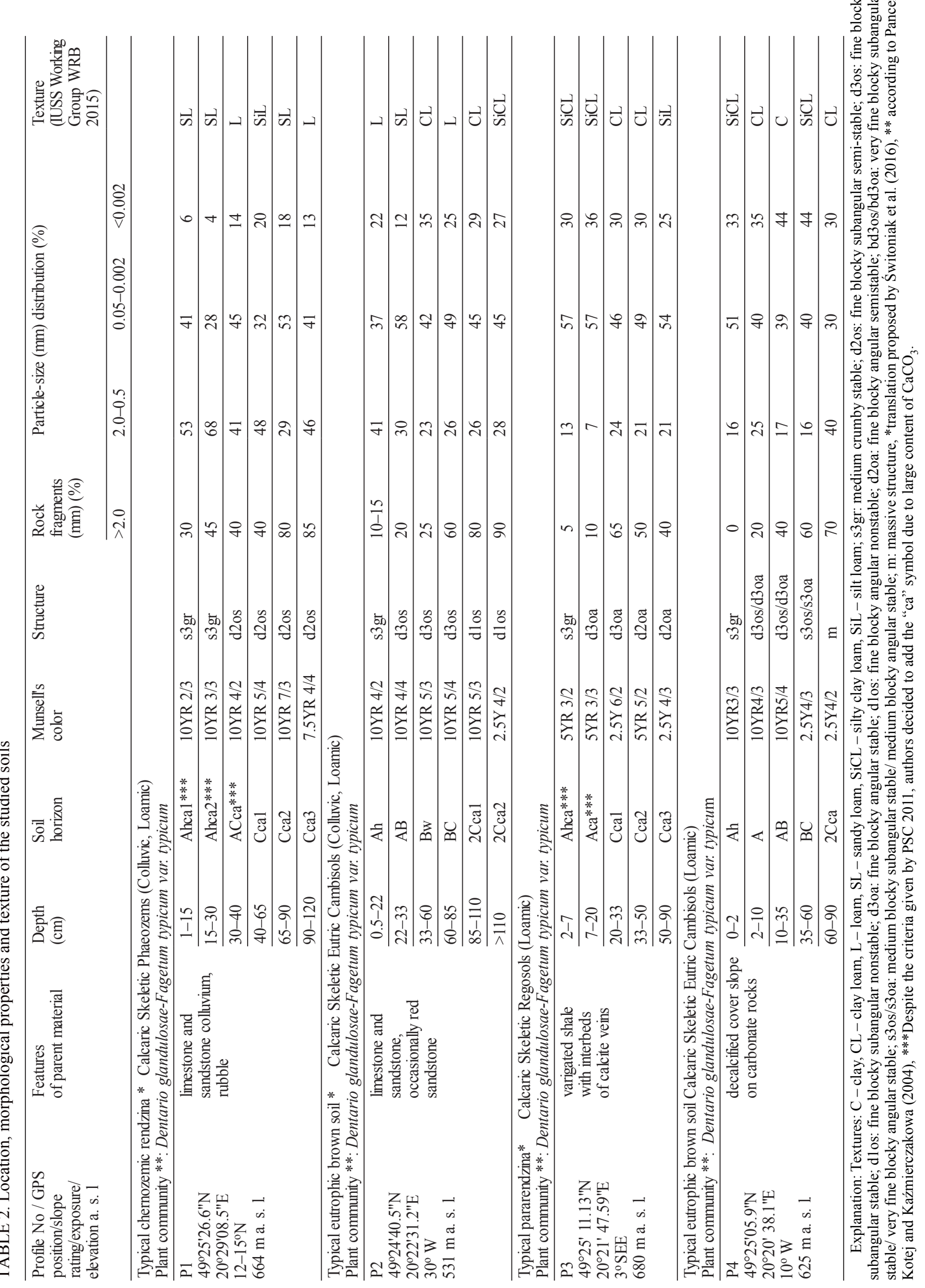


Munsell's scale was defined with "Revised Standard Soil Color Charts"(Oyama and Takehara 1970). Particlesize distribution was determined by hydrometer-sieve method according to Polish Standard (1998). For the determination of $\mathrm{pH}$ values, a potentiometric method was employed. The $\mathrm{pH}$ was measured in $\mathrm{H}_{2} \mathrm{O}$ and $1 \mathrm{M}$ $\mathrm{KCl}$ solution, in a ratio of 1:2.5 (w/v). Organic carbon content was determined using the potassium dichromate and Mohr's salt, without the calcium carbonate removing (Lityński et al. 1976). Total nitrogen was measured using LECO ${ }^{\circledR} \mathrm{CNS} 2000$ apparatus at Department of Soil Science and Soil Protection, University of Agriculture, Kraków. Estimation of the $\mathrm{CaCO}_{3}$ content was performed by treating the soil with hydrochloric acid (Lityński et al. 1976). Total potential acidity (TPA) were extracted in $0.5 \mathrm{M}$ of sodium acetate at $\mathrm{pH} 8.2$, while the sum of exchangeable bases $\left(\mathrm{Ca}^{2+}, \mathrm{Mg}^{2+}, \mathrm{Na}^{+}\right.$and $\left.\mathrm{K}^{+}\right)$were extracted in $1 \mathrm{M}$ $\mathrm{NH}_{4} \mathrm{Cl}$ at $\mathrm{pH} 7.0$ (Kociałkowski et al. 1984) and analysed with ICP-OES Optima $7300 \mathrm{DV}$ at Department of Agricultural and Environmental Chemistry, University of Agriculture, Kraków.

\section{RESULTS}

Investigated soils were located on hills with different slope inclination and with northern (P1), western (P2, P4) and south-eastern (P3) exposition (Table 2). Thicknesses of soils were diverse (Table 2). Soils, which were derived from colluvial material (P1, P2, P4) were thicker than soil developed directly on variegated shale (P3). Soil horizons in profiles $\mathrm{P} 1$, $\mathrm{P} 2$ and $\mathrm{P} 4$ were mainly yellow-brown to brown color. Soil from profile $\mathrm{P} 3$ was red-brown, which was caused by the primary red color of parent variegated shale (Table 2).

Topsoil horizons of all profiles consist of stable crumby aggregates. In the subsoil horizons, more or less stable, blocky angular and blocky subangular aggregates were present (Table 2).

Mineralogical compositions of soils horizons was similar in every analyzed sample (Fig.). Soil horizons contain quartz and calcite as the main phases. Small amounts of feldspars, micas and some clay minerals (1.47 and $0.71 \mathrm{~nm}$ peaks) were present. Proportion of quartz and calcite differs from sample (horizon) to sample.

The amount of gravel fragments usually was increasing with the depth of profile (Table 2), but amount of coarse fraction was often more than $10 \%$ even in the uppermost horizons (Table 2). Despite the various proportions of sand, silt and clay in the horizons, most of samples were classified as loam (Table 2). Commonly, the most abundant grain size fraction in analysed horizons were silt- and clay-size grains. In the humus horizon of profile $\mathrm{P} 1$, amount of sand was higher than the amount of silt and clay (Table 2).

Reaction of the soils was weakly acidic to neutral ( $\mathrm{pH}$ in the range from 7.8 to 8.8 in $\mathrm{H}_{2} \mathrm{O}$ and from 6.5 to 7.6 in $\mathrm{KCl}$ solution). In each profile, $\mathrm{pH}$ values (both in $\mathrm{H}_{2} \mathrm{O}$ and $\mathrm{KCl}$ ) increase with the depth (Table 3). The most acidic sample was soil P4, which does not contain any carbonates in the upper $60 \mathrm{~cm}$ of the profile.

Investigated soils were characterized by high concentration of total organic carbon (TOC) and total nitrogen (Table 3). In the topsoil horizons, TOC ranged from 44.9 to $89.0 \mathrm{~g} \cdot \mathrm{kg}^{-1}$ and $\mathrm{N}$ ranged from 3.7 to 5.6 $\mathrm{g} \cdot \mathrm{kg}^{-1}$. In the profiles P1, P2 and P3, TOC was present even in the deepest horizons. High values of $\mathrm{C}: \mathrm{N}$ ratio in humus horizons (usually higher than 10) indicate maturity of organic matter. The highest values of C:N ratio was identified in profile $\mathrm{P} 3$ at the depth from 20 to $33 \mathrm{~cm}$ (Table 3 ).

In the deeper and middle parts of soils, concentration of $\mathrm{CaCO}_{3}$ were noticeably higher than in humus horizons, with exception of $\mathrm{P} 4$, where carbonates occur only in parent material (Table 3, Fig.). The lowest content of $\mathrm{CaCO}_{3}$ in parent material was indicated in profile P2 $\left(173.0 \mathrm{~g} \cdot \mathrm{kg}^{-1}\right)$, whereas the highest amount of $\mathrm{CaCO}_{3}$ in profile P1 $\left(703.0 \mathrm{~g} \cdot \mathrm{kg}^{-1}\right)$ were found (Table 3).

Cation exchange capacity (CEC) of investigated soils was high, e.g. in case of profile P4, it reached $258.0 \mathrm{mmol} \cdot \mathrm{kg}^{-1}$ in the humus horizon (Table 3). Soil sorption complex in all investigated profiles was mostly saturated by basic cations (Table 3 ), from which $\mathrm{Ca}^{2+}$ predominated. The ranged of $\mathrm{Ca}^{2+}$ cations was from 103.7 to $225.0 \mathrm{mmol} \cdot \mathrm{kg}^{-1}$ (Table 3). Saturation of soil by $\mathrm{Mg}^{2+}, \mathrm{K}^{+}$and $\mathrm{Na}^{+}$cations was much lower (Table 3). Total potential acidity (TPA) of soils was low and ranged from 1.1 to $13.4 \mathrm{mmol} \cdot \mathrm{kg}^{-1}$ (Table 3). Usually, higher values of TPA were typical of topsoil horizons (Table 3 ). The sum of exchangeable bases was high (Table 3).

Based on the FAO-WRB (IUSS Working Group WRB 2015) classification, analyzed soils were classified as Calcaric Skeletic Phaeozems (Colluvic, Loamic) - soil P1; Calcaric Skeletic Eutric Cambisols (Colluvic, Loamic) - soil P2; Calcaric Skeletic Regosols (Loamic) - soil P3 and Calcaric Skeletic Eutric Cambisols (Loamic) - soil P4. According to PSC (2011) soil P1 was classified as typical chernozemic rendzina, soil P2 and P4 as typical eutrophic brown soils, whereas P3 was classified as typical pararendzina (Table 2). Taking into consideration the criteria given by third and fourth edition of PSC $(1974,1989)$ it should be mentioned that all studied soils supposed to be classified as pararendzinas. 


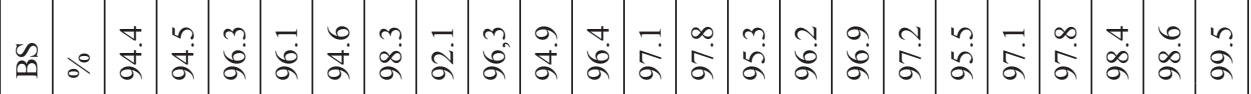

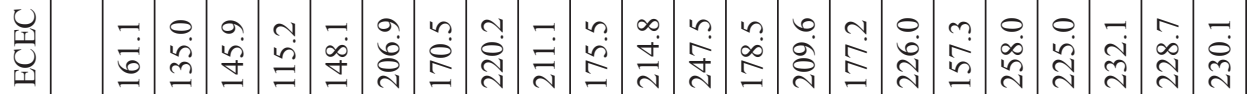

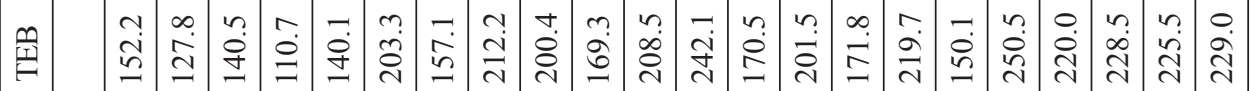

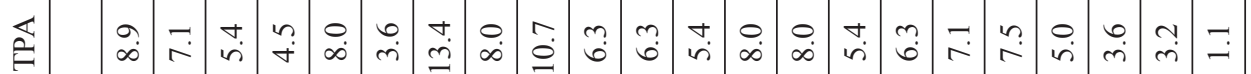

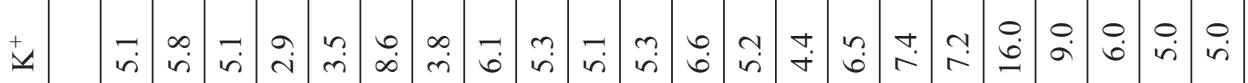

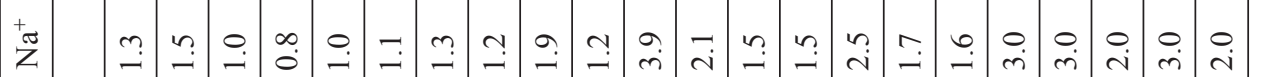

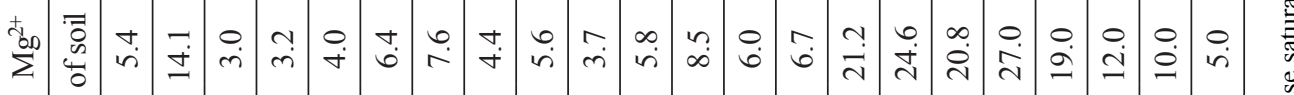

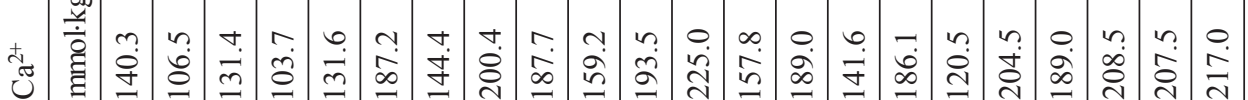

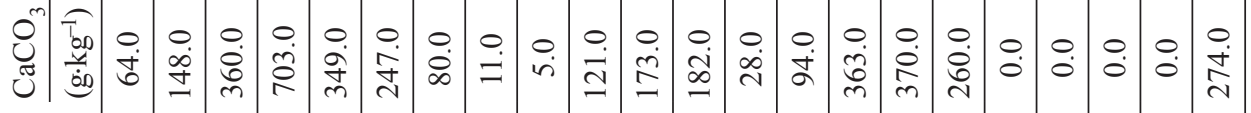

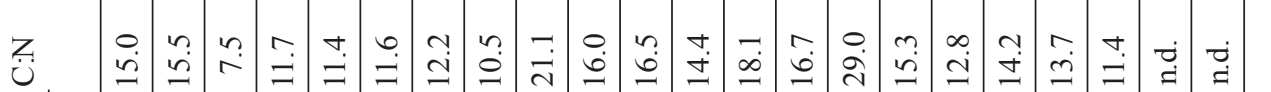

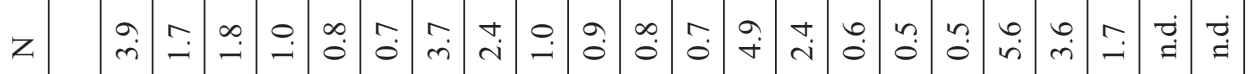

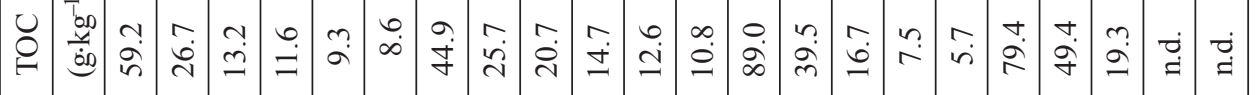

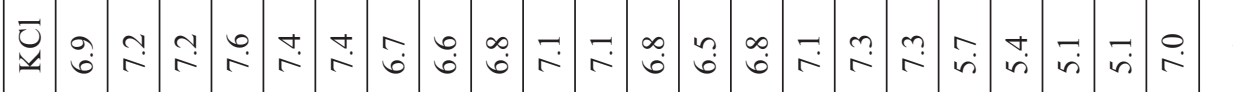

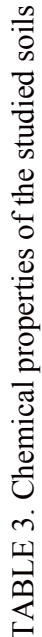

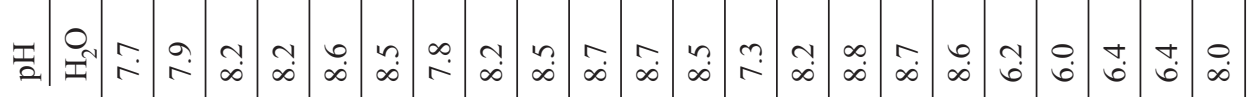

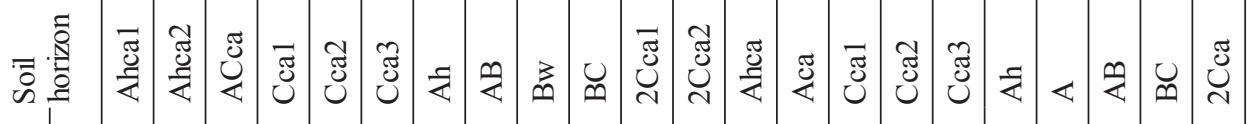

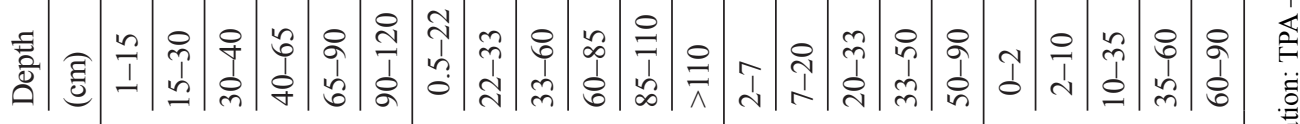

$=$

$\Sigma$

$\approx$

舍 


\section{DISCUSSION}

According to PSC (2011) four types of carbonate-rich soil can be distinguished - rendzinas (raw rocking rendzinas, proper rendzinas, brown rendzinas and chernozemic rendzinas), pararendzinas, soils with the admixture of allochtonous silicate materials, named mixed rendzinas and typical eutrophic brown soils. Nowadays, distinction of those soils can occur only through their chemical and physical properties as well as varied parent material from which those soils may derived. Based on the division by PSC (2011) and field research, analysed soils supposed to be classified as pararendzinas. However, there are some shortcomings, which provide a basis for discussion about the detailed criteria as well as the place of pararendzinas in PSC (2011), especially according to the soils formed on the slopes of the mountain's areas.

Traditional approach assumed that the type of parent material of carbonate-rich soil from the Pieniny Mts. area has the decisive influence on shaping their physical and chemical properties (Zasoński 1992, Skiba et al. 2002, Kacprzak 2003, Kabała et al. 2008, Lasota et al. 2014). Nevertheless, analysed soils have been formed from weathering alterations of rock material dislocated on the slopes with stratified arrangement named cover beds (Kasprzak and Derkowski 2007). Cover beds, especially in Pieniny Mts., contain both carbonate and non-carbonate material and are often enriched with admixture of foreign material. Hence, diverse particle size distribution within every profile is caused by various shares of parent material such as limestone, sandstone and shale within cover beds (Table 2).

Content of silt fraction was generally higher in humus horizons in comparison with deeper ones (e.g. profile P3), which is thought to be related with accumulation of eolian materials with the additions of autochthonic materials in surface horizons of studied soils (Zasoński 1981, Kacprzak and Żyła 2006, Kabała et al. 2008). Similarly, the amount of quartz and plagioclase is higher in upper horizons, which can be also result of eolian input of those minerals in the investigated soils (Fig.). In addition, a large diversity of individual grain fraction content between horizons (e.g. profiles P1, P2, P4) was connected with slopewash and solifluction processes (Zasoński 1981, Kacprzak and Skiba 2000, Kacprzak 2003). Taking into consideration the mineral composition it should be mentioned that only qualitative phase identification were performed, so it is impossible to estimate the exact proportions of soil forming minerals, but rough estimations due to intensity of the highest XRD peaks determine that the proportions of quartz and calcite varied from soil to soil (Fig.). The Figure also shows that the amount of calcite decreases in a upper parts of soil profile.

All analysed soils fulfil the diagnostic criterion for pararendzinas concerning carbonates content, i.e. they have more than $15 \% \mathrm{CaCO}_{3}$ in the parent material (PSC 2011). Content of $\mathrm{CaCO}_{3}$ was varied in studied soils (Table 3 ) and mainly depended on different amounts of calcite in the parent material and selective weathering (Zasoński 1992). Moreover, the

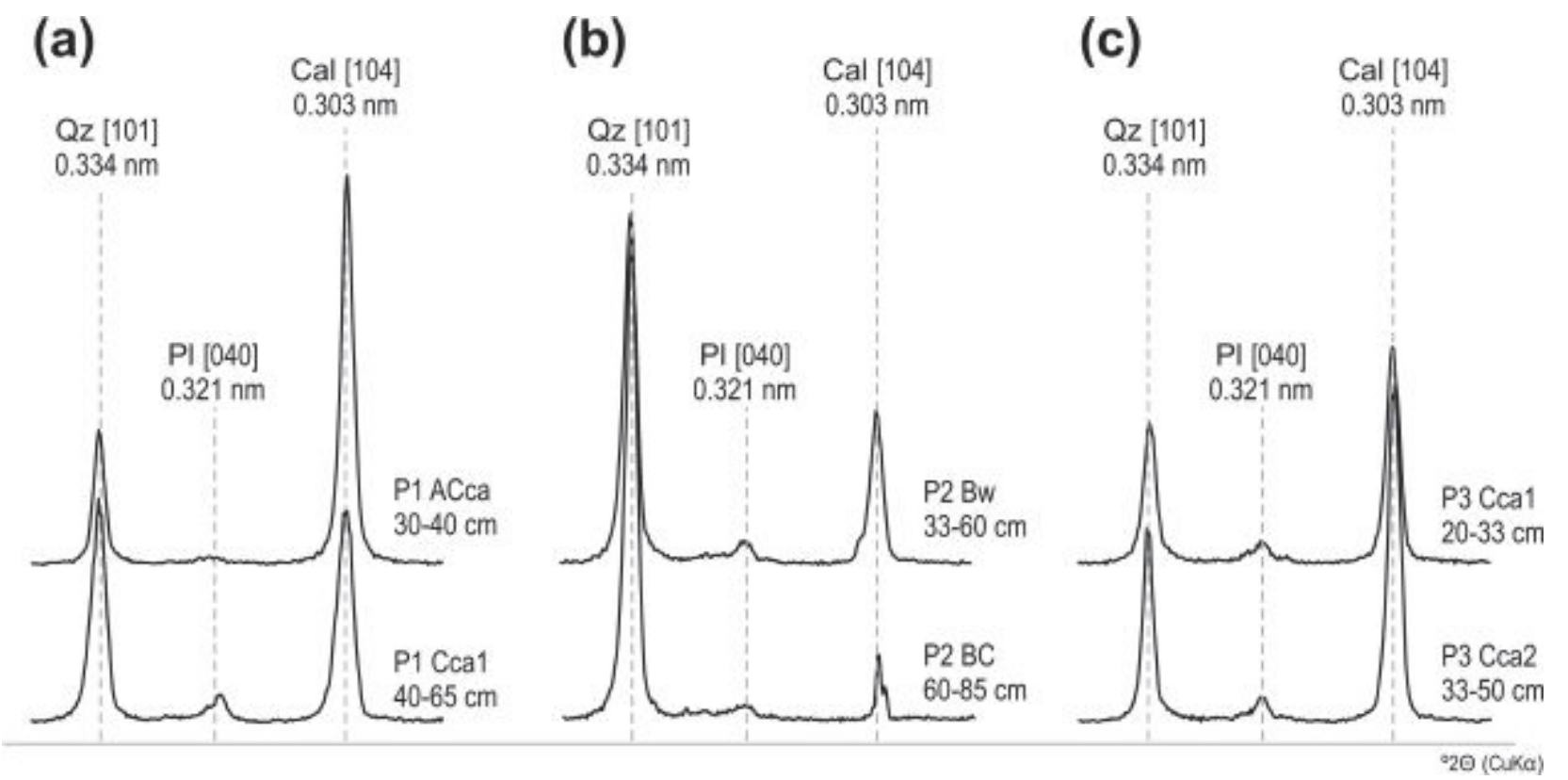

FIGURE. Fragments of X-ray diffraction patterns with peaks of quartz (101), plagioclase (040) and calcite (104) of raw powder samples from mineral horizons of soils P1 (a), P2 (b) and P3 (c). 
investigated soils were characterized by the lower content or lack of $\mathrm{CaCO}_{3}$ in the surface horizon or middle part of profiles (Table 3). Zasoński (1993) related the arrangement of $\mathrm{CaCO}_{3}$ with the intensity of dissolution and leaching of carbonates in soil genetic horizon. According to his studies, pararendzinas formed from Carpathian's flysch were characterized by slow decalcitization, which includes both bedrocks fragments and weathered material, wherein the rate of decalcitization was slower in skeleton parts. In contrast to those studies, varied content of $\mathrm{CaCO}_{3}$ within the analysed soils formed from cover beds, can be a result of impoverishment of carbonate rocks with calcium carbonate compunds during the transport. It can be stated that the lower content of $\mathrm{CaCO}_{3}$ in the rock fragments can be also a result of additives of non-carbonate materials (Zagórski 2003, Kacprzak and Derkowski 2007).

Taking into consideration the admixture of foreign silicate material, it can be assumed that studied soil profiles could be classified as mixed rendzinas. Nevertheless, due to the fact that according to current PSC (2011) pararendzinas can be formed e.g. from sandstones, high content of quartz and silicate minerals is expected; thus the division based on the type of rock, is quite inconsistent in this case. Following the current division, given by PSC (2011), the admixture of silicate material could decide about belonging to individual groups (Kabała 2014).

Investigated soils were characterized by high content of organic carbon in surface horizons. In studied soils, organic carbon occurred even in the deepest horizons (Table 3). This is the result of translocation of organic matter and plant's deep-rooting within loose skeleton's soil material. A similar phenomenon was described by Zasoński and Skiba (1988), and Zasoński (1992, 1993). A large content of clay fraction in soils causes aggregates stabilization and carbon sequestration. According to Zasoński (1992), mineral colloids affect the stabilization of humic compounds in a B and $\mathrm{C}$ soil horizon. Likewise, on the aggregates stability, $\mathrm{Ca}^{2+}$ ions have a large influence (Ben-Hur et al. 1985, Amézkrta 1999).

Furthermore, sorption properties of carbonate-rich soils were mostly influenced by the impact of the carbonate bedrock and a large amount of carbonate rock fragments within the soil profile.Similar relationships were described by Zasoński (1993). A characteristic feature of carbonate-rich soils was high base saturation and especially large shares of $\mathrm{Ca}^{2+}$ cations (Zasoński 1992, 1993; Caravaca et al. 1999, Jonczak 2010, Tomašić et al. 2013). The large content of $\mathrm{Ca}^{2+}$ cations was related with abundance of $\mathrm{CaCO}_{3}$ in parent material. According to Zasoński
(1992) and Jaworska et al. (2008) it can be stated that some soils can cause minor extension of sorption capacity. The binding of calcium ions in soil is strong enough, hence the high concentration of $\mathrm{Ca}^{2+}$ ions occur despite the absence of or low content of $\mathrm{CaCO}_{3}$ (e.g. profile P4) (Table 3).

The high sorption capacity and composition of sorption complex of studied soils were also influenced by large contents of organic carbon and high amount of clay fraction. The sorption is strongly related to the type of clay minerals. The $1.4 \mathrm{~nm}$ peak may indicate presence of the smectite, vermiculite or chlorite, but more analysis to provide more detailed identification of the clay fraction should be performed. The obtained results were similar to described for pararendzinas and rendzinas at the area of Tatra Mts. and Pieniny Mts. by several authors (Zasoński 1992, 1993; Jaworska and Długosz 1996, Zagórski 1999, Miechówka 2002).

Reaction within the studied soils, between the genetic horizons was variable and mostly depended on $\mathrm{CaCO}_{3}$ content; thus, $\mathrm{pH}$ values increased with depth, where the content of $\mathrm{CaCO}_{3}$ was higher (Table 3). Acidification of humus horizons caused the dissolution of $\mathrm{CaCO}_{3}$ by organic acids which originated from the products of litter decomposition and forest vegetation (Miechówka 1989). This process has also resulted in higher total potential acidity in humus horizons than in the deeper horizons (Table 3).

Analysing the reaction within studied soils, initially classified as pararendzinas, can be stated that most horizons have higher $\mathrm{pH}$ values, measuring in $\mathrm{H}_{2} \mathrm{O}$ than ranges (6.0-7.5) given by PSC (2011). Due to the fact that other properties (e.g. content of $\mathrm{CaCO}_{3}$ ) made it possible to classify the studied soils as pararendzinas, perhaps upper limit of $\mathrm{pH}$ values given by PSC (2011) should be discussed. In particular, similar $\mathrm{pH}$ values in pararendzinas were described by other authors (Zasoński 1993, Kacprzak and Żyła 2006, Zaleski et al. 2006). The similar situation occurs in case of the soil's depth criterion (the pararendzinas' thickness). Taking into consideration the guidelines given by PSC (2011) weakly developed soils should have not more than 50 centimetres depth. The thickness of all soil profile was more than $50 \mathrm{~cm}$, thus, following this criterion, analysed soils should be automatically degraded from order of weakly developed soils. According to PSC (2011), there is no specific information about the pararendzinas, which caused the contradictions during the classification. It should be mentioned that in the previous edition of PSC (1989), pararendzinas could have thickness at least $50 \mathrm{~cm}$. The authors suggest that the thickness of the weakly developed soil should be more clarified 
taking into account the specific conditions of these soils formation.

It should be mentioned, that according to PSC (2011), in the pararendzinas description (symbol sequence), presence of secondary (pedogenic) calcium carbonate within soil profile is necessary. However, the description of pararendzinas contains information that lithological (primary) calcium carbonate derived from the directly underlying weathered rocks (e.g. sandstones or shales) within the soil profile can be found as well. According to Kabała (2014) the following division has been proposed: rendzinas include the soils, where carbonates would be mainly primary, lithological origin (including lake chalk), whereas the soils, where carbonates originated mainly from pedological processes are considered as pararendzinas. Such approach could unambigously resolve the problem of rendzinas and pararendzinas separation.

Furthermore, in a situation where within the rendzinas', cambic horizon is forming, those soils should be classified as brown rendzinas. However, there is no such analogy for pararendzinas. Zasoński (1992) described pararendzinas with partially developed cambic horizon, that did not meet thickness criterion for brown soils' cambic horizon according to PSC (2011). It seems, that this type of soil should be considered as the transitional stage between pararendzinas and brown soils. Detailed analysis of $\mathrm{P} 2$ and $\mathrm{P} 4$ profiles allow to identity the cambic horizon within these soil profiles. According to PSC (2011) brown pararendzinas are characterized by occurrence of cambic horizon, but do not fulfil the thickness criterion. It should be mentioned that the cambic horizon within the P2 and $\mathrm{P} 4$ profiles have more than $15 \mathrm{~cm}$ (Table 2). In such as situation $\mathrm{P} 2$ and $\mathrm{P} 4$ profiles must be positioned in the order of brown earths soils, type typical eutrophic brown soils (PSC 2011). Nevertheless, based on the symbol sequence record of soil horizon given by PSC (2011), within the parent material of eutrophic brown soils the secondary calcium carbonate, similarly as in case of pararendzinas should be identified. Referring to Kabała (2014), following on this record, evolution of soil formed from parent material, which is rich in lithogenic calcium carbonate, would be impossible.

Detailed analysis of chemical and physical properties of profile $\mathrm{P} 1$, allowed for identification mollic horizon according to PSC (2011). Identification of mollic horizon within the soil profile is the foundation to classify profile P1 to the seventh order black soils, type of chernozemic rendzinas. Mollic horizon within P1 is mainly the result of organic matter deposition from upper parts of the slope and in lesser degree as an effect of in-situ accumulation.
However, classification of profile $\mathrm{P} 1$ as chernozemic rendzinas is limited by the criteria given by PSC (2011). P1 profile was characterized by high content of rock fragments in A horizon (Table 2) what did not meet the criterion for chernozemic rendzinas. Furthermore, according to rendzinas description, these soils were formed from carbonate or sulfate rocks and in PSC (2011) is no mention about even small amount of the non-carbonate rock fragments occurrence, which have been found in $\mathrm{P} 1$ profile classified as chernozemic rendzinas. Restrictions mentioned above concerning to carbonate and non-carbonate rock fragment are not included in IUSS Working Group WRB (2015). Nevertheless, there is no more suitable classification for this soil according to PSC (2011), what also reflect general problem with classification of carbonate-rich soils. Authors suggest that this aspect should be more clarified.

It can be assumed that studied soils could comply with most of criteria concerning pararendzinas given by PSC (2011) such as the type of parent material, $\mathrm{CaCO}_{3}$ content, TOC content and saturation of sorption complex with bases. Nevertheless, P1 profile was classified as typical chernozemic rendzinas due to occurrence the mollic horizon. Moreover, within soils P2 and P4 cambic horizon have been formed, thus those soils were classified as brown earths soils. Some of soils' properties do not fulfil all of criteria for pararendzinas or those information are not given by PSC (2011). Among those criteria, the range of $\mathrm{pH}$ values, thickness of pararendzinas profiles, admixture of eolian silt as well as issue of secondary carbonate should be resolved. Based on the conducted research, the authors suggest that some of criteria concerning on carbonate-rich soil should be discussed and furthermore clarified, that includes in particular: i) determination of the boundary between rendzinas and pararendzinas; ii) clarification of the range of $\mathrm{pH}$ values and thickness for pararendzinas; iii) specification of the direction of pararendzinas evolution due to formation a cambic horizon iv) determination and field recognition of differences between primary and secondary carbonates.

\section{CONCLUSIONS}

1. Based on the research, some similarities of morphological, chemical and physical, as well as mineralogical features within the analysed carbonate-rich soils can be found. Nevertheless, despite the wide spectrum of carbonate-rich soils according to Polish Soil Classification (2011), there are some issues with unambiguous classification due to the occurrence of carbonate and non-carbonate 
rock material within the soil profile. Authors noticed that carbonate-rich soil may be classified in to different units (orders, types).

2. The conducted studies have allowed to state that soils can be classified as: P1 - typical chernozemic rendzina, P2 and P4 - typical eutrophic brown soils, whereas P3 - typical pararendzina.

3. Taking into consideration determined chemical and physical properties, it can be found that investigated soils were influenced by not only the in-situ weathering material but also by rock material which have been transported and deposited as a result of slope processes. Furthermore, the lack or lower content of $\mathrm{CaCO}_{3}$ in surface and middle part of analysed soils was most likely a result of the impoverishment of rock material during the transport on the slope.

\section{REFERENCES}

A Natural and Genetical Classification of Polish Soil (Przyrodniczo-genetyczna klasyfikacja gleb Polski), 1956. Roczniki Nauk Rolniczych. Seria D: 1-96 (in Polish with English summary).

Adamczyk B., Greszta J., Olszowski J., 1980. Mapa typów gleb Pienińskiego Parku Narodowego. Skala 1:10 000. Polska Akademia Nauk, Zakład Ochrony Przyrody i Zasobów Naturalnych w Krakowie, Państwowe Przedsiębiorstwo Wydawnictw Kartograficznych, Warszawa: 1 ark.

Amézkrta E., 1999. Soil Aggregate Stability: A Review Journal of Sustainable Agriculture 14(2-3): 83-151.

Arbeitskreis für Bodensystematik der Deutschen Bodenkundlichen Gesellschaft, 1998. Systematik der Böden und der Bodenbildenden Substrate Deutschlands, Kurzfassung. Mitt. Dt. Bodenkundl. Ges. 86: 135-180, Oldenburg.

Ben-Hur M., Shainberg I., Bakker D., Karen R., 1985. Effect of soil texture and $\mathrm{CaCO}_{3}$ content on water infiltration in crusted soil as related to water salinity. Irrig. Sci. 6: 281-294.

Caravaca F., Lax A., Albaladejo J., 1999. Organic matter, nutrient contents and cation exchange capacity in fine fractions from semiarid calcareous soils. Geoderma 93: 161-176.

Fajer M., Waga J.M., 2012. Gleby rezerwatu przyrody „Góra Zborów”. [In:] Pełka-Gościniak J. (eds) Acta Geographica Silesiana 19-27 (in Polish with English summary).

FAO, 2006. Guidelines for soil description. fourth ed. 109 (Rome). Genetical Classification of Polish Soils (Genetyczna klasyfikacja gleb Polski), 1959. Roczniki Gleboznawcze - Soil Science Annual 7(2): 1-103 (in Polish with English summary).

IUSS Working Group WRB, 2015. World Reference Base for Soil Resources 2014, update 2015. International soil classification system for naming soils and creating legends for soil maps. World Soil Resources Reports No. 106. FAO, Rome, p. 182.

Jaworska H., Długosz J., 1996. Kationowa pojemność wymienna i skład kationów wymiennych gleb płowych wytworzonych z utworów fluwioglacjalnych okolic Mochełka. Roczniki Gleboznawcze - Soil Science Annual 47(3): 53-61 (in Polish with English summary).
Jaworska H., Kobierski M., Dąbkowska-Naskręt H., 2008. Cation exchange capacity and the content of exchangeable cations in luvisols of various texture. Roczniki Gleboznawcze - Soil Science Annual 59(1): 84-89 (in Polish with English summary).

Jonczak J., 2010. Sorption and buffer properties of soils of spring niches in the Jarosławianka River valley (Sławieńska Plain). Roczniki Gleboznawcze - Soil Science Annual 59(3): 45-51 (in Polish with English summary).

Kabała C., Bogacz A., Waroszewski J., Ochryra S., 2008. Influence of slope cover-beds structure on the morphology and properties of podzols in subalpine zone of the Karkonosze Mts. Roczniki Gleboznawcze - Soil Science Annual 59(1): 90-99 (in Polish with English summary).

Kabała C., 2014. Classification of Polish Soils - Current State and Further Development. Roczniki Gleboznawcze - Soil Science Annual 65(2): 91-98 (in Polish with English summary).

Kacprzak A., Skiba M., 2000. Uziarnienie i skład mineralny jako wskaźniki genezy utworów macierzystych gleb w katenie stokowej Małej Rawki (Bieszczady Zachodnie). Roczniki Bieszczadzkie 9: 169-181 (in Polish with English summary).

Kacprzak A., 2003. Slope covers as the soil parent material in the western Bieszczady Mts. Roczniki Gleboznawcze-Soil Science Annual 54(3): 97-110 (in Polish with English summary).

Kacprzak A., Drewnik M., Uzarowicz L., 2006. Development and transformation directions of talus carbonate soils in the Pieniny National Park. Pieniny - Przyroda i Człowiek 9: 41-50 (in Polish with English summary).

Kacprzak A., Żyła M., 2006. Micromorphology of "brown pararendzina soils" (Skeleti-Endoleptic Cambisols) developed from slope covers in the Pieniny Mts. Pieniny - Przyroda i Człowiek 9: 51-61 (in Polish with English summary).

Kacprzak A., Derkowski A., 2007. Cambisols developed from cover-beds in the Pieniny Mts. (southern Poland) and their mineral composition. Catena 71(2): 292-297.

Kobylecka S., 1981. Stosunki litologiczno-glebowe Wyżyny Żarkowsko-Częstochowskiej. UŚ, Katowice: 84 s. (in Polish with English summary).

Kociałkowski W., Pokojska U., Sapek B., 1984. Przewodnik do oznaczania pojemności sorpcyjnej gleby. Prace Komisji Naukowych PTG. Warszawa: 94 s. (in Polish).

Krysiak S., Tołoczko W., Niewiadomski A., 2010. $\mathrm{CO}_{2}$ respiration in soils of field ecosystems formed from different origin parent material. Ochrona Środowiska i Zasobów Naturalnych 42: 144-150 (in Polish with English summary).

Lasota J., Błońska E., Zwydak M., Wanic T., 2014. The use of particle size distribution of soils in estimating quality of mountain forest sites. Forest Research Papers 75: 253-262 (in Polish with English summary).

Lemkowska B., Sowiński P., 2008. Evolution of „post-lake rendzinas" in the landscape of the Mazurian Lakeland. Roczniki Gleboznawcze - Soil Science Annual 54: 134-140 (in Polish with English summary).

Lityński T., Jurkowska H., Gorlach E., 1976. Chemical-agricultural analysis. Warszawa PWN: 332 pp. (in Polish).

Łuszczyński J., Łuszczyńska B., 2009. Current resources of the population of Adonis vernalis L. in the Niecka Nidziańska basin. Herba Polonica 55: 20-29 (in Polish with English summary).

Miechówka A., 1989. Charakterystyka geochemiczna rędzin tatrzańskich wytworzonych z dolomitów. Część I. Ogólna cha- 
rakterystyka gleb i niektóre dane mineralogiczne. Roczniki Gleboznawcze - Soil Science Annual 40(2): 83-105 (in Polish with English summary).

Miechówka A., 2002. Selected properties of rendzinas occurring under dwarf pine in the Tatra National Park. Roczniki Gleboznawcze - Soil Science Annual 53(1/2): 5-12 (in Polish with English summary).

Niemyska-Łukaszuk J., Miechówka A., Zaleski T., 2002. The soils of Pieniny National Park and their threats. Pieniny - Przyroda i Człowiek 7: 79-90 (in Polish with English summary).

Niemyska-Łukaszuk J., Zaleski T., Miechówka A., 2004. Characteristics of the soils of the Pieniny National Park. Studia Naturae 49: 33-41 (in Polish with English summary).

Niemyska-Łukaszuk J., Miechówka A., Mazurek R., 2010. Charakterystyka jednostek taksonomicznych gleb Babiogórskiego Parku Narodowego (w granicach z 1996 roku). [In:] Lasota J. (eds.) Operat Gleby Babiogórskiego Parku Narodowego, Taxus, Warszawa: 11-52 (in Polish with English summary).

Oyama M., Takehara H., 1970. Revised Standard Soil Color Charts. Research Council for Agriculture, Forestry and Fisheries, Japan.

Paluszek J., 2010. The changes of soil cover as a result of erosion. Prace i Studia Geograficzne 45: 279-294 (in Polish with English summary).

Pancer-Kotej E., Kaźmierczakowa R. (red.), 2004. Mapa roślinności (zbiorowisk) Pienińskiego Parku Narodowego 1:10 000. [In:] R. Kaźmierczakowa (red.) Charakterystyka i mapa zbiorowisk roślinnych Pienińskiego Parku Narodowego, „Studia Naturae" 49: 1 ark.

Polish soil classification (Systematyka gleb Polski), 1974. Roczniki Gleboznawcze - Soil Science Annual 25(1): 1-148 (in Polish).

Polish soil classification (Systematyka gleb Polski), 1989. Roczniki Gleboznawcze - Soil Science Annual 40(3/4): 1-150 (in Polish).

Polish soil classification (Systematyka gleb Polski), 2011. Roczniki Gleboznawcze - Soil Science Annual 62(3): 1-193 (in Polish).

Polish Standard, 1998. Soil and mineral soil materials-Sampling and determination of particle size distribution. PN-R-04032, Polish Committee for Standardization, Warszawa: 97 (in Polish).

Rybicki R., 2010. The differentiation of soil cover of eroded terrains on the example of Opatówka river basin. Prace i Studia Geograficzne 45: 295-305 (in Polish with English summary).

Skiba S., Drewnik M., Zaleski T., 2002. Soil map of the Pieniny National Park (Polish Western Carpathians) in the international taxonomy Pieniny - Przyroda i Człowiek 7: 91-95 (in Polish with English summary).

Soil Taxonomy, 1999. A Basic system of soil classification for making and interpreting soil surveys. Soil Survey Staff. USDANRCS. Agric. Handb. 436. US Gov. Printing Office, Washington DC. 869.

Sowiński P., Lemkowska B., 2010. Macro-elements in soils of post-lake depressions of the Olsztyn Lakeland. Roczniki Gleboznawcze - Soil Science Annual 2: 87-94 (in Polish with English summary).
Świtoniak M., Kabała C., Charzyński P., 2016. Propozycja anglojęzycznych nazw jednostek Systematyki gleb Polski. Roczniki Gleboznawcze - Soil Science Annual 67(3): 103-116. (in Polish with English summary).

Tomašić M., Zgorelec T., Jurišić A. Kisić I., 2013. Cation exchange capacity of dominant soil types in the Republic of Croatia. Journal of Central European Agriculture 14(3): 937-951.

Zagórski Z., 1999. Micromorphology and some properties calcareous soils from Male Pieniny. Roczniki Gleboznawcze Soil Science Annual 50(1-2): 115-126 (in Polish with English summary).

Zagórski Z., 2001. Mikromorfologiczna charakterystyka węglanów w rędzinach wytworzonych z margli kredowych. Roczniki Gleboznawcze - Soil Science Annual 52(1/2): 79-88 (in Polish with English summary).

Zagórski Z., 2003. Mineralogiczne i mikromorfologiczne wskaźniki genezy i właściwości rędzin wytworzonych ze skał różnych formacji geologicznych, Fundacja „Rozwój SGGW”, Warszawa: 124 s. (in Polish with English summary).

Zaleski T., Kacprzak A., Maj K., 2006. Pedogenetic conditions of retention and filtration in soils formed from slope covers on the example of a selected catena in the Pieniny Mts. Polish Journal of Soil Science 39(2): 185-195 (in Polish with English summary).

Zaleski T., Mazurek R., Gąsiorek M., Wanic T., Zadrożny P., Józefowska A., Kajdas Bartłomiej, 2016. Soils of the forest monitoring areas in the Pieniny National Park. Pieniny - Przyroda i Człowiek 14: 3-15 (in Polish with English summary).

Zasoński S., Skiba S., 1988. Chemiczne i mikromorfologiczne właściwości gleb wapniowcowych okolic Cieszyna. Roczniki Gleboznawcze - Soil Science Annual 34: 71-90 (in Polish with English summary).

Zasoński S., 1981. Główne kierunki glebotwórcze na utworach pyłowych podgórza Wielickiego. Część I. Ogólna charakterystyka gleb i niektóre właściwości chemiczne. Roczniki Gleboznawcze - Soil Science Annual 32(2): 13-141 (in Polish with English summary).

Zasoński S., 1992. Warstwy krośnieńskie jako skała macierzysta pararędzin fliszowych (na przykładzie gleb Wzgórz Rymanowskich). Roczniki Gleboznawcze - Soil Science Annual 43(3/4): 77-90 (in Polish with English summary).

Zasoński S., 1993. Gleby wapniowcowe wytworzone z wybranych ogniw litostratygraficznych fliszu wschodnich Karpat. Cz. I. Ogólna charakterystyka gleb. Roczniki Gleboznawcze - Soil Science Annual 44(3/4): 121-133 (in Polish with English summary).

Zasoński S., 1995a. Gleby wapniowcowe wytworzone z wybranych ogniw litostratygraficznych fliszu wschodnich Karpat. Cz. II. Właściwości mikromorfologiczne. Roczniki Gleboznawcze - Soil Science Annual 46(1/2): 119-134 (in Polish with English summary).

Zasoński S., 1995b. Gleby wapniowcowe wytworzone z wybranych ogniw litostratygraficznych fliszu wschodnich Karpat cz. III. Skład mineralny frakcji ilastej. Roczniki Gleboznawcze - Soil Science Annual 46(3/4): 45-57 (in Polish with English summary).

Received: June 15, 2016

Accepted: February 20, 2017

Associated editor: t. Uzarowicz 


\section{Zróżnicowanie morfologicznych, fizycznych i chemicznych właściwości gleb zasobnych $w$ węglan wapnia na obszarze Pienin (południowa Polska)}

Streszczenie: Gleby zasobne w węglan wapnia charakteryzują się dużym zróżnicowaniem udziału węglanowych lub niewęglanowych składników mineralnych w substracie glebowym, które decydują o ich właściwościach. W pracy przedstawiono wyniki badań czterech gleb pobranych z obszaru Pienińskiego Parku Narodowego. Celem badań była charakterystyka i klasyfikacja gleb wytworzonych z węglanowych i zasobnych w węglan wapnia materiałów macierzystych. Zostało to osiagnięte przez oznaczenie morfologicznych, fizycznych i chemicznych właściwości, jak również oznaczenie składu mineralogicznego wybranych gleb, bogatych w węglan wapnia, występujących w polskich Pieninach. Badane gleby zaklasyfikowano jako rędzinę czarnoziemną typową (P1), gleby brunatne eutroficzne typowe (P2, P4) oraz pararędzinę typową (P3) według kryteriów podanych przez Systematykę gleb Polski (2011)

Gleby położone były na stokach o różnym nachyleniu i ekspozycji. Materiałem macierzystym gleb P1, P2 i P4 były pokrywy stokowe z dominującym udziałem szkieletu pochodzącego z piaskowców oraz mniejszym udziałem szkieletu wapiennego. Gleba P3 wykształciła się z bogatych w kalcyt czerwonych łupków pstrych. Gleby charakteryzowały się trwałą strukturą agregatową: gruzełkową, angularną lub subangularną. Były średnio lub silnie szkieletowe, głównie o uziarnieniu glin z dużym udziałem frakcji pyłowej. Zawartość $\mathrm{CaCO}_{3}$ zawierała się w granicach od 0,0 to $703,0 \mathrm{~g} \cdot \mathrm{kg}^{-1}$. Odczyn gleb był od lekko kwaśnego w poziomach próchnicznych do alkalicznego w poziomach spagowych. Gleby te cechowały się bardzo wysokim wysyceniem kompleksu sorpcyjnego przez kationy zasadowe, wśród których przeważały jony $\mathrm{Ca}^{2+}$, co wynikało z węglanowego lub zasobnego w węglany materiału macierzystego i podłoża geologicznego. Wysoka pojemność sorpcyjna wynikała z dużej zawartości materii organicznej i frakcji iłowej. Biorąc pod uwagę chemiczne i fizyczne właściwości stwierdzono, że badane gleby wytworzone zostały nie tylko w wyniku wietrzenia skał in-situ ale były również wynikiem transportu i depozycji materiału skalnego podczas procesów stokowych. Niska zawartość lub brak $\mathrm{CaCO}_{3} \mathrm{w}$ górnej lub środkowej części profilu glebowego była związana z zubożeniem materiału skalnego w trakcie jego transportu po stoku.

Stowa kluczowe: gleby zasobne w węglan wapnia, gleby Karpat, Phaeozems, Cambisols, Regosols 